\title{
CRITICAL ANALYSIS ON HISTORIOGRAPHY OF GAMELAN BEBONANGAN IN BALI
}

\author{
Hendra Santosa \\ Departement of Karawitan, Indonesia Institute of the Arts Denpasar
}

\begin{abstract}
Historical sources on gamelan Bebonangan refer to the different shapes and forms of the ensemble. It inevitably results in perplexity on the origin, shapes, and forms of gamelan $B e$ benongan. The paper, therefore, aims to redress the confusion by rewriting it through critical history, a type of criticism on historical sources related to the term gamelan Bebonangan in Bali. The method used for the paper is historical approaches that include heuristics, criticism, interpretation, and historiography as the finale. The word bebonangan is not found in historical sources of Balinese karawitan in the form of Old Javanese literature, which is today preserved in Bali and the Balinese literature itself. The only literary work that mentions these pencon-ed instruments is the Book of Pararaton, calling the as reyong instruments. The Book of Prakempa refers to the instruments in names such as reyong barangan and reyong pangageng. By indicating that the reyong instrument becomes the main instrument, one may expect peculiarity in the claims. It may be pointed out that opinions have been led in the beginning by the foreign influence to impose the view to the Balinese to challenge their own identity and, at the same time to be applauded for their arts and culture.
\end{abstract}

Key words: bebonangan, gamelan, critical history, Pararaton, reyong

\begin{abstract}
ABSTRAK
Sumber sejarah tentang gamelan Bebonangan yang menunjuk bentuk dan wujud yang berbeda. Hal ini tentu saja menyebabkan kesimpang siuran tentang asal-usul dan wujud gamelan Bebonangan itu sendiri. Oleh karenanya penulisan ini bertujuan untuk meluruskan kesimpangsiuran yang terjadi dengan menuliskannya melalui kritik terhadap sumber-sumber sejarah istilah gamelan Bebonangan di Bali. Metode yang dipergunakan yaitu metode sejarah yaitu heuristik, kritik, interpretasi atau penafsiran, dan terakhir adalah historiografi. Kata bebonangan tidak ditemukan dalam sumbersumber sejarah karawitan Bali yang berupa literatur kesusastraan Jawa Kuna yang sekarang diawetkan di Bali dan literatur kesusastraan Bali sendiri. Satu-satunya karya kesusastraan yang menyebutkan instrumen berpencon ini adalah kitab pararaton yang menyebutnya dengan instrumen reyong. Prakempa menyebutkan instrumen-instrumen gamelan Bebonangan antara lain reyong Barangan dan reyong Pangageng. Merujuk hal tersebut dimana instrumen reyong merupakan instrumen utama, maka tentulah hal ini menjadi sebuah keanehan. Sepertinya telah terjadi penggiringan sejak awal, adanya pengacauan asing telah memaksakan orang Bali untuk mempertanyakan dasar identitas mereka, pada saat yang sama mereka juga mendapat sanjungan untuk seni dan budayaannya.
\end{abstract}

Kata Kunci: Gamelan, Babonangan, Reyong, Pararaton, Sejarah Kritis 


\section{INTRODUCTION}

In 1824, German historian Leopold von Ranke published the book titled Geschichten der romanischen un germanischen Volkër (history of Germany and the Germans), which includes the period from 1494 to 1514 . He described and compared the history of Germany with all the superior traits possessed by the mighty Romans. Ranke claimed that to develop a critical historical research method id by investigating the 'credibility of the sources' (source criticism). His wellknown motto in historical research and writing is that a historian should hold on to "wat ist eigenlig geschicte" (what happened). Only by that approach can the truth from the past be revealed. Concerning the claim, this writing of the critical history of gamelan bebenongan in Bali is also investigating the credibility of the sources as a source of internal criticism.

Balinese karawitan (traditional voice -vocal and instrumental- arts)artists recurrently mention gamelan bebenongan, yet today the instruments have been equated with gamelan balaganjur, as also referred to gamelan kalaganjur. However, the sources that mention gamelan kalaganjur have never been discovered in Bali. Besides, sources containing gamelan kalaganjur strangely are spread around Java, but the presence of the gamelan kalaganjur itself has never been found until today.

The Book of Pararaton refers to the reyong instruments used by the Sundanese in the War of Bubat, while it is clearly known that the reyong is Balinese original instrument. The Aji Gurnita dan Prakempa manuscripts (known as lontar, referring to the type of leaf used to write the manuscripts) indicate the gamelan utilized to sharpen the weapons as gamelan bebonangan. Then in 1924, Kunst, pointed at the picture of reyong klentangan as bebonangan, and in 1931, McPhee showed the picture of gamelan balaganjur as gamelan bebonangan. Later in 1982, Bandem referred it to the ponggang (two tuned metal gongs) instruments. In 1998, Sukerta pointed to one of the types of gamelan bebonangan, pro- ceeded by Bakan in 1999 by calling gamelan balaganjur as bebonangan.

Two Dutch ethnomusicologists Jaap Kunst and C.J.A. Kuns van Wely in 1925 discussed gamelan carabelen in a unique chapter in the pages 178-182 in their book titled De Toonkunst Van Bali. In page 222, Kunst inserted picture number 24 with a caption "Bebonangan Van Desa Boeningan (Boeleleng)", which indicates it is gamelan bebonangan. However, it was a picture of two men holding kendang centungan, two men with reyong klentengan, and two children carrying kempur. Later, a photograph from Heyting, L.C. collection from KITLV numbered 31111 was captioned "Reyong of Bonang, afkomstig uit desa Banjoening nabij Boeleleng month 8 the year 1923 " which referred to a picture of reyong klentangan. In his book Music in Bali, Colin McPhee intended to correct the photograph shown by Kunst as reyong klentangan and explained it in Chapter 15 on gamelan angklung from page 234 to 255 . The explanation was then illustrated in Picture 70 and Picture 71 with the caption "Antique reyong in the gamelan Angklung". In the next illustration page, McPhee displayed five photographs of gamelan balaganjur from Picture 3 to Picture 7 naming them as gamelan bebenongan as if they were the real pictures of gamelan bebonangan.

\section{RESEARCH METHOD}

This research is conducted using the historical method, which is, as pointed by Louis Gottschalk (1975, p. 32), a process of critically examining and analyzing records and artifacts from the past. The historical method includes heuristics, criticism, interpretation, and historiography aiming at reconstructing the old times (Garraghan 1957, pp. 33-69; Gottschalk: 1975, pp. 17-19; Kartodirdjo 1982). The first step is heuristics by collecting various data and sources related to the topic of this research, such as the Book of Pararaton, Prakempa, and Aji Gurnita manuscripts, De Toonkunst van Bali, Music in Bali, and other books on gamelan bebonangan. The next step is through criticism by examining the credibility of the sources or also 
known as internal criticism by comparing the works. The third step is the interpretation of facts and historical sources. Two approaches conduct interpretation: analysis (outlining) and synthesis (combining) and includes verbal interpretation, which relates to language, vocabulary, context, and translation. Verbal interpretation aims to explain the meanings of words or sentences (Garraghan, 1957, p. 321; Herlina, 2014, pp. 36-55). The last step is historiography, a written report in multidimensional form.

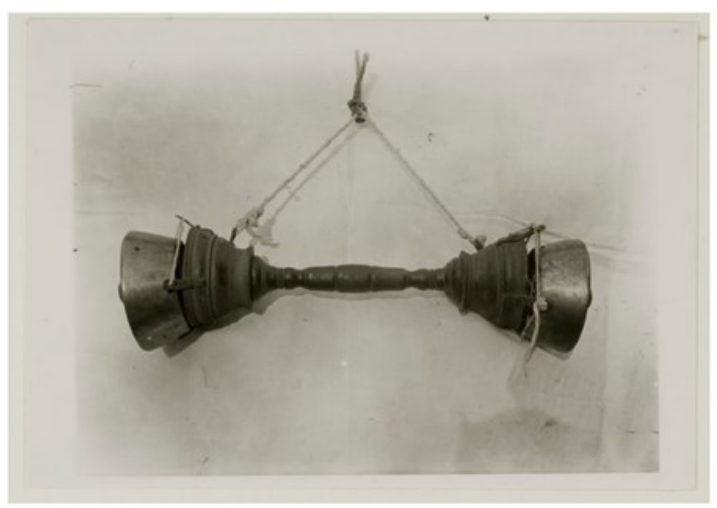

Figure 1. Reyong of Bonang, 1923

Source: Heyting, L.C., collection KITLV number 31111

\section{RESULTS AND DISCUSSION}

Balinese karawitan encyclopedia records that bebonangan is derived from the word "bonang" which means pencon (referring to the parts of gamelan made out of metal). The term bebenongan is used to call one of the presentations of the musical piece (garap gending) in a set of gamelan or gending (musical composition) kalaganjur/ balaganjur (Sukerta, 1998, p. 18). In Balinese musical encyclopedia, Bandem argues that bonang whose other names include ponggang and bebonangan is a barungan (ensemble) comprises of several percussive pencon-ed instruments such as reyong, trompong, kajar, kempli, kempur, and gong. Gamelan bonang uses two kendangs (two-headed drum) played using panggul (mallet) performed in ritual processions (Bandem, 1982, p. 5). It was evident that the two experts in Balinese karawitan call and refer to gamelan balaganjur for gamelan bebonangan presented at a parade. These claims contradict traditional sources of Prakempa and Aji Gurnita, saying that gamelan bebonangan is still performed in a place.

Bandem and Suartaya state the repertoire of gamelan bebonangan consists of gilak (ostinato) songs where terompong (a set of twelve gongs) is played as melody. Kendang as the rhythm starter, kajar (small kettle-like instrument), kempli (small horizontal gong), kempul (small hanging gong), and gong as timekeeper; meanwhile, reyong plays kotekan (interlocking figuration). It is performed to convoy a ritual procession (Bandem, 1982, p. 5; Suartaya, 1993, p. 130). Sukerta's, Bandem's, and Suartaya's arguments are the opposite of notions stated in Prakempa that bebonangan consists of two gongs: lanang (male) and wadon (female), one kempul, one bebende (another type of gong similar to kajar used to play off the beat), two ponggangs (dang and dung), one kemong, two sets (tungguh) of large reyong, two sets of reyong babarangan, two kendangs: lanang and wadon with papanggulan beats. It also mentions parts such as one rebab (bowed-string instrument), one suling (wind instrument resembling tin whistle made of bamboo), one pair of large gangsa (a type of metallophone), one pair of medium gangsa, one pair of small gangsa, one pair of jegogan (the lowest-pitched gangsa carrying bass melody), one pair of jublag (six-keyed gangsa with higher pitch than jegogan, one pair of penyacah (seven-keyed gangsa); all instruments are played in ngumbang-ngisep (literary means "bee sucking honey") system. In conclusion, Prakempa describes the whole ensemble of gamelan bebonangan to be both comfortable and hard to carry during a procession. In contrast, Suartaya only notes the portable and assembled instruments without mentioning the more difficult ones.

\section{Bebonangan in Traditional Sources}

Bebonangan is mentioned in Prakempa manuscript in the catur muni-muni (four gamelans) part where three lyrics require gamelan bebonangan in lyrics $37,67,68,69$, 
and 71 . The lyric 37 says that "Sawateking Bhuta Kala amangun Gambelan Babonangan ngaran", which means "all the devils (bhuta kala) created gamelan and called it gamelan Babonangan" (Bandem, 1986, p. 66). Meanwhile, in lyrics 38, it says that "mwang ikang Babonangan ring Sapta Petala stananya", which means "and the Babonangan belongs to Sapta Petala" (Bandem, 1986, p. 66). The following is an excerpt from lyric 67.

Iki purwakaning Aji Mredangga ngaran, yan hana swakaryan sang rabhu, anut aneng gagambelan babonangan mwang gong katu genahnya, mangge ring wesmanira sang prabhu, ri kala hana swakaryanira sang natha. Stananing gagambelan ring bancingah agung, ikang babonangan maring yasa kiwaning gopura stananya. Gong ika ring yasa tengah stananya, maka pengapiting gopura karwa gagambelan ika.

\section{Meaning:}

This is the origin of Aji Merdangga, when ceremonies were held for the king (prabu). the music must be babonangan and the gong should be arranged in such a position, played in the king's palace during the ceremonies, the place where all the instruments were must be in bancingah agung. The babonangan's place must be decorated in the left side of the gate (candi bentar), the gong's place was decorated in the right side of the gate, so the gate was flanked by the gong and the babonangan where the music came from (Bandem, 1986, pp. 86-87).

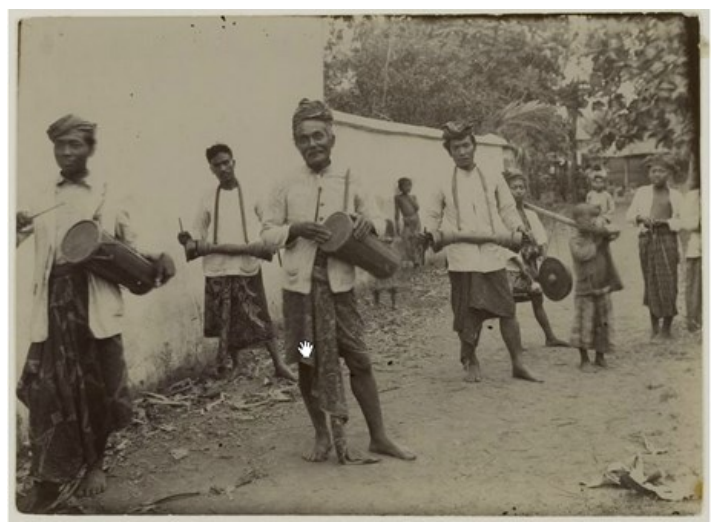

Figure 2. Bebonangan van desa Boeningan (Buleleng)

Source: Jaap Kunst, Book of de Toonkunst van Bali
Bancingah agung is the gate where people go inside and outside the palace where the right side is occupied by the gong (possibly gamelan pelegongan) and the left side is where the bebonangan is placed. It can be compared the positions of gamelan bebonangan and gamelan carabalen in which both are placed beside the gate outside the palace.

Next, in lyrics 68 , it says

Lyan malih hana wwang akarya suka duka, yogya gagambelan ika ianangge ring stananing swakarya, yadyapi babonangan atawa gong pada juga kotamnya. Wenang juga tinabuh rikalaning apujawali maring sanggar kabuyutan mwang payangan mwang sarwa tatiwan lwirnya. Pitra Tarpana, Sawa Wedana katekatekeng Dewa Yadnya, pada wenang gelaraken gagambelan ika. Mangkana Kojaranya.

Meaning:

Meanwhile, when people were working for joy and sorrow (religious ceremonies), the music might be played where the ceremonies took place while bebonangan and gong were also the major part. They may also be played during pujawali (pidolan or religious rituals in the pura or temples) or in Kawitan Studio, Parahyangan, and for all deathrelated works such as Pitra Tarpana, Sawa Wedana, and Dewa Yadnya. All may play the music. That's how it was (Bandem, 1986, pp. 86-87).

Gamelan bebonangan may be played during pujawali in Kawitan Pura, Parahyangan, to accompany working for ceremonies.

The lyric 69 states

Kunang papatutan Babonangan lawan Gong Patutan lima juga lwirnya, dang, ding, deng, dung, dong. Gendingnya yan babonangan ketug bhumi ngaran. Yan gong grehakasa ngaran. Kunang katatwanya babonangan ika tiniru maring sor bhumi rikalaning sawateking bhutakala apupul. Sedeng mangkana pinalu gegambelan babonangan ika, sang prabhu mwang asraman senjata ring lebuh agung.

Meaning:

The difference between patutan (fivetone subsets) babonangan and five-pathet gongs: dang, ding, deng, dung, dong. The babonangan song (gending) Ketug 
Bhumi was the name. [It was played with] the grehakasa gong, that's the name. About the history of the babonangan, it could imitate from the underworld where the bhutakalas gathered; as the sounds from babonangan were played, the earth was trembling, causing fear and horror as if the world had been destroyed by the sounds of $b a$ bonangan, which could sharpen the weapons. All the king's bebarungan (processional ensemble) and armory were made the way to the special line in the palace (Bandem, 1986, pp. 86-87).

The lyric affirms that the sounds of gamelan bebonangan raise fear and horror that they can be used to sharpen the weapons. It is also the royal gamelan placed in bancingah agung. It appears to me that gamelan bebonangan is played for showing the troop's strength through the different kinds of weapon handled by the warriors.

Finally, in lyric 71, it says.

Kunang babarungan Gong Babonangan kengetakena kayeki, Gong roro lanang wadon, swaranya angumbang ding angisep. Kempul sanunggal swaranya ding alit angumbang. Bebende sanunggal swaranya dang bhora. Ponggang satungguh swaranya dang dung. Kemong sanunggal swaranya dung angumbang alit. Rereyongan pangageng kalih tungguh swaranya, dang dung satungguh, deng dung satungguh, rereyongan barangan kalih tungguh swaranya dang dung satungguh, deng dong satungguh. Kendang kalih lanang wadon saha papanggulan. Rebab sanunggal, suling ageng apasang, suling babarangan apasang, sama ngumbang ngisep. Jegogan sapasang, jublag sapasang, panyacah sapasang, gangsa ageng sapasang, gangsa menengah sapasang, gangsa alit sapasang, sama ngumbang ngisep. Gumanak tigang siki, genta orag kalih pancer menengah. Cengceng alit tigang wungkul, cengceng menengah kalih wungkul, cengceng ageng sawungkul. Jankep kayeki.

Meaning:

On the bebarungan for babonangan gong, you must remember carefully [this ensemble]: gong, two lanangs and wadons with angumbang angisep beats. One kempul with ding angisep beats. One bebende with ghora (Skt. awful) dang sounds, ponggang satungguh with dang dung sounds, one kemong with dung angum- bang alit (small, little) sounds. Two tungguh of large rereyong (pangageng): one tungguh of dang dung sounds and one tungguh of deng dung sounds, two tungguh of rareyongan babarangan: one tungguh of dang dung sounds and one tungguh of deng dong sounds. Two kendangs of lanang and wadon along with papanggulan. One fiddle (rebab), one pair of large sulings, one pair of suling babarangan also with ngumbang ngisep technique. One pair of jegogan; one pair of jublag; one pair of penyacah; one pair of large gangsa; one pair of medium gangsa; one pair of small gangsa played in ngumbang ngisep, too. Three gumanak (tube chimes) and two genta orag (bell tree) in medium pancer (additional notes). Three pairs (cakep) of cengceng (cymbals): two pairs of medium cengceng and one pair of large cengceng. And they were all complete (Bandem, 1986, pp. 88-89).

This lyric confirms the ensemble of gamelan bebonangan which is entirely different than what is described balaganjur bebonangan. The aforementioned gamelan in the lyric is too complicated for a processional performance because it requires large instruments and demands special treatments too elaborate for a cavalcade. If it is manifested in a live performance, the treatments will be the same as those for gamelan carabalen played during a procession, videlicet by carrying them above the shoulders negating the principles of war gamelan which are easy to carry and facilitates maneuvers necessary in a battle.

We shall trace the history of gamelan bebonangan for the exact years. Literary manuscripts recorded, as aforesaid, nothing on bonang or bebonangan. Only in the Aji Gurnita and Prakempa is bebonangan mentioned, that internal criticism is imperative for the two traditional sources. I assume that there has been a "balinizing" ("pembalian") towards the word bonang to become bebonangan, as in the word panggul (carrying something above the shoulder) that becomes pepanggulan and others. A series of the question then arises: why was not it called gamelan rareyongan derived from the word reyong? Or why did not moncol (knob) for 
the word pencon become memoncolan? Has there been a constraint of terms to reyong to become bonang? These questions should be analyzed for further researches as the answers are still challenging to find.

Sudirga (2017) argues that the terms pelog and salendro (two most common scales in gamelan) were brought by the Kokar (Konservatori Karawitan Indonesia of Indonesian Karawitan Conservatory, now School of Karawitan) teachers educated in Java in the 1960s (Sudirga, 26 April 2017). The terms themselves have yet to be found in Balinese society. The people recognize the terms saih which means harmony (laras) and patutan along with the name of the gamelan used to play them, such as patutan gong, patutan gambang, patutan angklung, and others. If the thesis is proven to be eligible, the terms in both manuscripts should be questioned of the existing long before the Dutch colonized Bali before Indonesia's independence in 1945. This doubt is also apparent in the term bebonangan in the two traditional sources, and they refer to the extinct gamelan. The latter argument can be considered more reliable as Sudirga noted that "when he was a child, he heard what was mentioned in Prakempa and Aji Gurnita, but the name was gamelan kalaganjur, not bebonangan, and now the gamelan has been fused into gamelan gong kebyar (Sudirga, 26 April 2017). I have to agree with the thesis because if the terms pelog-salendro came to Bali in the later, bebonangan in the manuscripts might also be founded later. The term bebonangan seems to be an imposed thought, but they were not derived from the Dutch researcher in 1925 and American scholar in 1931. The question remains; is it what Picard argues?

Although this statement oversimplifies a complex and less known process, it can be argued that the Balinese scholars were trying to give meaning to the drastic changes that resulted from the forced opening of its social space. They formulated Balinese socially as a religious minority, the last stronghold of Hinduism characterized by distinctive cus- toms. The Orientalists assured the Balinese that they were true "artists." It happened just at the time of the Balinese program (Balisering), which excited the attention of the Balinese to its cultural heritage. Thus both colonialism and tourism in the early stages have contributed to the debate about religious relations, customs, and cultural arts. The debate and the concepts it adopts is now the Balinese frame of reference in terms of cultural identity. But the debate has been driven from the start by the fact that when the foreign confusion forced the Balinese to question the basis of their identity at the same time, the flattering praises of their culture also urged them to explain it explicitly in a way that non-Balinese would understand. (Picard, 2006, p. 29).

A document titled Citra Bali dalam Arsip (2007) (The Images of Bali in Archives) reveals that:

Before the arrival of the Dutch, Balinese art was Folk Art, where its coaching was located within the palace grounds. Therefore it could also be called palace art. After Bali fell into colonizers, the Balinese arts have experienced disintegration. But this factor developed the art in Bali through the lower classes that continued to grow mainly through schools ... (2004, p. 7 [trans]).

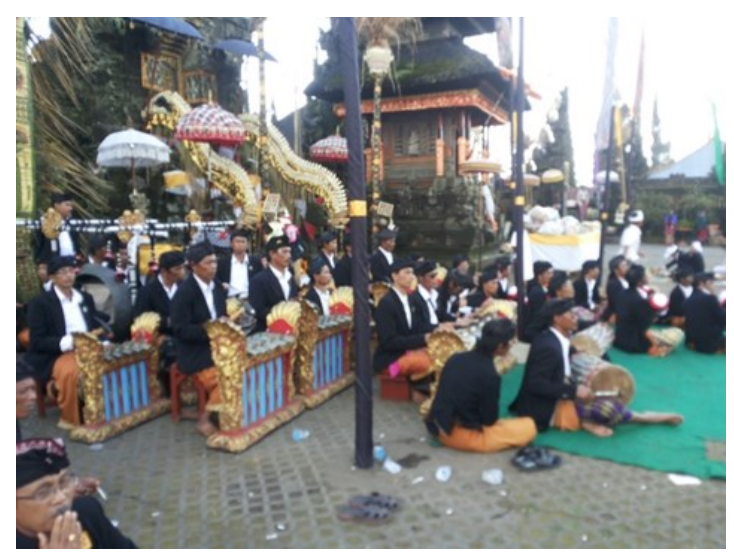

Figure 3. Gamelan Babonangan in Batur vilage 2016.

Source: Pande Gede Mustika collection 
The shift of coaching from the palace to the people has developed the creativity among the Balinese. I also argue that there has been a relocation of shows from the palace (puri) to the temple (pura). The shift has stripped down the power and the authority of the royals to the people and compulsion among them applied to the guarding soldiers of the puri.

\section{Bebonangan in the Dutch Colonial Sources}

A photograph in a Dutch-published book de toonkunst van Bali in 1925 was captured in Buningan, a village in Buleleng picturing four adult men carrying a gamelan ensemble that consisted of two small kendang and two reyong klentangan, and two young boys with a gong in their shoulders. The caption in the photograph says that the ensemble was gamelan bebonangan from Buningan village, Buleleng. The Dutch data contradicts with the fact that the ensemble in the photograph was reyong klentangan. Meanwhile, an American scholar, Colin McPhee in 1931 released a photograph of gamelan angklung and called it reyong klentangan. It can be assumed that the Dutch researcher's naming it bonang for the Balinese gamelan has been influenced by his previous research on the Javanese gamelan. In Java, the gamelan recognizes the terms such as the bonang instruments, gending bonang, and gending bonangan, which are different from reyong instruments. There has never been any data nor source recording. The term bonang has been brought to Bali.

In his book, Music in Bali: A Study in form and Instrumental Organization in Balinese Orchestral Music (1966, pp. 234-255), McPhee seems to explain gamelan angklung and raise the question on when the instruments were unified and named so. In the illustration section, there are five photographs of gamelan balaganjur (Picture 3-7). Picture 3 is captioned "Gamelan Bebonangan, showing the kendang wadon and kendang lanang"; Picture 4 "Reong players in the gamelan Bebonangan"; Picture 5 "Bonang players in the gamelan Bebonangan";
Picture 6 "Chengcheng players in the gamelan Bebonangan"; and, Picture 7 "gong wadon and lanang in the gamelan Bebonangan". Although the book was published in 1966, the pictures were taken between 19311938 (Bali 1928 - Repatriating Bali's Earliest Music Recordings, 1930s Films and Photographs, 2017). They were captured by McPhee himself, and brought before Kunst's.

McPhee says that the percussions were generally played in gilak or gagilakan. The lead melody in the ensemble is reyong played in kakilitan. In the north and east Bali, gamelan bebonangan is performed during a funeral in the sea or in a cemetery. The results from McPhee's survey show that the term bonang refers to the four pencon played not in the different tunes, larger than reyong, and given to the individiual players and carried in a professional ensemble known as gamelan bebonangan. By playing the rhythm separately, the four players would create an ostinato in the short rhythmic pattern together replacing the melody (McPhee, 1966, p. 29). However, Picture 5 in McPhee's book clearly illustrates reyong instruments that can be dispersed from the standard (tungguhan). It should be reaffirmed that in Balinese literature, in both Javanese and Balinese, the name bonang to refer to an instrument is not found. Instead, it is reyong as it is mentioned in Pararaton. The Book of Pararaton was written in the year of saka (Hindu luni-solar calendar) of "Keinginginan Sifat Angin Orang", or 1535 or 1613 AD, eleven years after the Dutch arrived in the island of Java. It remained anonymous and was written in Kawi or Old Javanese language with the latest entry recorded in 1481 (Pitono, 1965, p. 5). The term bonangan, in fact, can be found in Javanese literature.

Nasruddin Anshoriy notes an exciting notion on bonangan in the subtitle "Titi Raras Kraton" as follows.

From Sri Sultan I to Sri Sultan VII, the kerawitan trace (caking kerawitan) called nguju-nguju mainly refers to the sounds played with a gavel (sora) or gending bonangan. Therefore, the repertoire of 
the Mataram sounds is caled uyon-uyon soran. It is due to larasan called laras umjung. Harmony plays perfectly when beaten hard. The songs vociferously surge boasting masculinity, bravery, power, and handsomeness. If the melody is beaten gently, the harmony sounds billowy and rather inept. Laras umjung is derived from spun harmony or played out of tune or the interval between the harmonies is varied. (Anshoriy, 2008, p. 123 [trans]).

Anshory's note on the range of the sultans from Sri Sultan I to Sri Sultan VII is different than Sabdacarakatama's in his book Sejarah Keraton Yogyakarta in which he spans from Sri Sultan Sri Sultan Hamengku Buwono I to Sri Sultan Hamengku Buwono IX. The difference, however, is irrelevant to the topic of this paper, but we can see there is a relation between gamelan gending bonangan in Java and gamelan bebonangan in Bali, which has been most probably influenced by the Dutch researcher, proceeded by the American.

In Yogyakarta, gending bonangan is known as gending soran, a type of sound beaten hard and correctly performed before the sinden (singer) and the dalang (puppetmaster) enter or join the performance. As mentioned earlier, there is a structure of pegongan in a gending bonangan named tabuh pisan and the name of the gending is Pisang Bali. Since historical research on war gamelan is not part of a show structure, it is necessary to notice that the topic can be analyzed in terms of, among others, the structure of gending tabuh pisan of Pisang Bali in gending bonangan in Solo and tabuh pegongan in Bali.

\section{Bebonangan in Modern Sources}

Gending kalaganjur is not part of the repertoire of a specific ensemble so that it can be played both in pelog and salendro gamuts. There are three kinds of gending kalaganjur. Kalaganjur Bebatelan, Kalaganjur Bebonangan, and Kalaganjur Peponggangan (Sukerta, 1998, p. 72). Sukerta similizes gamelan kalaganjur and gamelan balaganjur. The categorization is also evident in Mi- chael B. Bakan's notion of gamelan balaganjur. In terms of balaganjur, bebonangan is a modern form of balaganjur by referring to the whole instruments in the ensemble. The names balaganjur and gamelan balaganjur will be used to refer to the modern standard form of the ensemble, which is the gamelan balaganjur bebonangan. Batel (a type of ensemble primarily used to accompany a shadow play) is personified as a form of tabuhan gilak whose structure is less complicated (Bakan, 1999, p. 42). This relates to Picture 2 in Kunst's captioned "Bebonangan van desa Boeningan Boeleleng."

Balaganjur is formed by instruments that include six to twelve pairs of cengceng kopyak (large crash cymbals), four pieces of reyong, one pair of ponggang, two pieces of kendang cedugan (lanang and wadon), one piece of, one piece of kempli, two large gongs, one kempur, and one bebende; some ensemble is even complemented with laughing instruments. The cengceng kopyak is played with kakilitan or cecandetan (the more subtle variation) techniques, with varying rhythmic patterns from negteg (beat of one) beats, telu (three) beats, and enam (six) beats where each of them consists of, among of which, polos, sangsih, and sanglot beats. Reyong carries the meody and is played in kakilitan technique. Gamelan balaganjur performs gilak numbers played in becat (upbeat), sedeng (midtempo), and adeng (slow tempo) (Dibia, 2012, pp. 125-126).

The question on when the gamelan performed in a procession starts to be called balaganjur has remained unclearly unanswered because there has been no record on this in any document. The word balaganjur itself is derived from two words, bala, which means a troop or a front, and ganjur which means walking. Therefore, epistemologically, balaganjur means a walking troop which connotation now is more closely associated with the name of gamelan (Suartaya, 1993, p. 129).

In his thesis, Pande Gede Mustika argues that in 1998, gamelan gong gede was duplicated for several instruments. They 
were referred to gamelan bebonangan whose ensemble included four pieces of penyacah, four pieces of jublag, one peponggangan, one bebende, one kempul, one pair of lanang -wadon gong, and twelve pairs of cengceng kopyak; they were produced by Sidha Karya company in Blahbatuh village, Gianyar (Wayan Pager). They call the set of gamelan bebonangan as tedun bebonangan, while the complete set of gamelan gong gede is referred to as tedun trompong (Mustika, 2006, p. 75). In the Penyineban (a closing ceremony of temple festival), gamelan gong gede would be descended (tedun) to the middle part of the temple (jaba tengah or madya mandala, the most sacred part of the temple) to join in Penyineb (closing) ceremony by performing slow percussive sounds (tabuh-tabuh lelambatan) accompanying the war-like march and metiti suara (a procession which has economic equality meanings) (Mustika, 2006, p. 169). Yudarta (2017) also writes in his article that gamelan bebonangan still can be found in Bangli Regency, in villages such as Batur and Sulahan. In Batur, gamelan bebonangan is primarily played for Baris (literally meaning lining up) dances as $B a$ ris Gede, Baris Tamiang, and Baris Bedil (Yudarta, 21 September 2017).

The reyong instruments are mentioned in the Book of Pararaton, wherein the stories of historical events in Singhasari and Majapahit empires period (the thirteenth century and the fourteenth century) are told. The language used in the Book is Middle Javanese, and the epos are composed in a prosaic manner. It is worth noting that The Book of Pararaton came from the Island of Bali in the sixteenth century (Pitono, 1965, p. 5). The word reyong is mentioned in the Book in Chapter III, whose translation is read as follows.

... Rangga Kaweni, Urang Siring, Satrajali, Jagat Saya, all soldiers of Sunda together they cheered. With the sounds of reyong (a type of percussion), the clamor was heard as a clap thunder. The king had died before it began, so did Lord Usus. Bhra Paramecwara departed to Bubat, unaware that many Sundanese were still left behind, while the other Sundanese heroes were still in the front (Pitono, 1965, p. 53 [trans]).

The Sundanese culture does not recognize the reyong instruments. Even today, they are familiar with the term bonang, which can be assumed coming as a set of gamelan named Sari Oneng was presented by Panembahan Prince or in the period of Rangga Gempol III Prince (1656-1706) rule to Sumedang Larang. The present is expected to be related to the legitimation grant for the Prince of Sumedang to govern in Sumedang Larang by the Panembahan Prince. The bonang instruments in gamelan Ajeng are named koromong, while those in gamelan Goong Renteng are the goong renteng themselves. Then how did the term bonang arrive in Bali? To this date, I have yet discovered any reference related to it.

Based on The Book of Pararaton, I assume that gamelan kalaganjur and the appellation of gamelan balaganjur can be presumed coming from the Gelgel period (the sixteenth century) where wars often occurred and gamelan functioned as a marching band during the procession of the troop leaving for the battle. Gamelan kalaganjur consists of peponggangan, reyong barangan, cengceng kopyak, kendang lanangwadon, gong lanang-wadon, kempul, and bebende. Kalaganjur was supposed to be played for ceremonial purposes in the palace, such as in a royal troop march in certain events as tumpak landep (a ceremonial day when offerings are presented for objects made of metal). The kalaganjur instruments can be retrieved from gamelan gong gede. The name changed into balaganjur presumably when the instruments are gradually taken to the march by the beat makers to join the soldiers. Today, as Suartaya notes, "several instruments in gamelan gong kebyar may be used for gamelan balaganjur ensemble; it only requires several cengceng kopyak or cymbals" (Suartaya, 1993, p. 130).

\section{CONCLUSION}

There have been confusion and misunderstanding in identifying gamelan bebonangan, gamelan kalaganjur, and gamelan 
balaganjur. I argue that gamelan kalaganjur in Bali refers to the name of gamelan mentioned in the Prakempa manuscript as gamelan bebonangan. Meanwhile, the word "bebonangan" is presumed to be derived from a Dutch researcher in 1925, as stated in the book de toonkunst van Bali, because the term bonang or bebonangan is not traced in any literary reference in Bali. Kunst, McPhee, and Prakempa/Aji Gurnita even have different credits on bebonangan as an object. If there was a reference on the name, Kunst and McPhee should name it based on the traditional sources. Still, it also can be expected that the two manuscripts use the term from colonial sources as it is suspected of opinion-leading and imposing, as Picard says. Another source, The Book of Pararaton calls it reyong which is actually the main instrument of gamelan kalaganjur presumably from the Gelgel period or in the sixteenth century used for the royal ceremonial purpose of what is now known as the Baris dance where the name of the dance depends on the weapons carried in the procession. In addition, gamelan balaganjur, which means the music accompanying the soldiers in Bali, where it comes from, refers to one gamelan only. In contrast, in the areas where the ensemble is spread, it relates to the function as accompanying music, meaning that several types of gamelan can be named as balaganjur.

\section{REFERENCES}

Anonymous. (2004). Citra Bali dalam Arsip. Jakarta: National Archives of the Republic of Indonesia.

Anshoriy, N. (2008). Pendidikan Berbasis Kebangsaan, Kesadaran Ilmiah Berbasis Multikulturalisme. Yogyakarta: LKiS Yogyakarta.

Aryasa, I. W. (1976/1977). Perkembangan Seni Karawitan Di Bali. Denpasar: A Sasana Budaya Bali Project.

Bakan, M. B. (1999). Music of the Death and New Creation: Experiences in the world of
Balinese Gamelan Beleganjur. Chicago: University of Chicago Press.

Bali 1928 - Repatriating Bali's Earliest Music Recordings, 1930s Films and Photographs. Retrieved May 12, 2017, from http://edwardherbst.net/?page_id=105.

Bandem, I. M. (1983). Ensiklopedi Gamelan Bali. Denpasar: Provincial Government of Bali.

Bandem, I. M. (1983). Ensiklopedi Tari Bali. Denpasar: Indonesian Academy of Dance.

Bandem, I. M. (1986). Prakempa sebuah Lontar gambelan Bali. Denpasar: ASTI Denpasar.

Dibia, I. W. (2012). Ilen-ilen Seni Pertunjukan Bali. Denpasar: Yayasan Wayan Geria.

Garaghan, S. J. G. (1957). A Guide to Historical Method. Edited by Jean Delanglez. New York: Fordhan University Press.

Hardjowardoyo, R. P. (1965). Pararaton. Jakarta: Penerbit Bharata.

Kunts, J., and Kuns van Wely, C. J. A. (1925). De toonkunst van Bali. Weltervrede: Koninklijk Bataviaasch Genootschaap.

Lubis, N. H. (2014). Metode Sejarah. Revised Edition. Bandung: Indonesian Historians Community Foundation, West Java Chapter.

McPhee, C. (1966). Music in Bali: A Study in form and Instrumental Organization in Balinese Orchestral Music. New Haven and London: Yale University Press.

Mustika, P. G. (2006). Pertunjukan Gamelan Gong Gede di Pura Ulun Danu Batur Desa Batur: Senuah Kajian Budaya. Thesis. Denpasar: Universitas Udayana.

Picard, M. (2006). Bali: Tourism Culturel et Culture Touristique. Terjemahan, Bali: Pariwisata Budaya dan Budaya Pariwisata. First Edition. Jakarta: KPG (Kepustakaan Populer Gramedia).

Suartaya, K. (1993). Drumband Tradisional Adi Merdangga Kreativitas Seni Berdimensi Universal. Mudra: Journal of Arts and Cultures, 1(1), 128-136.

Sukerta, P. M. (1998). Ensiklopedi Mini Karawitan Bali. Bandung: SatratayaIndonesian Performing Arts Community (MSPI). 